\title{
Opening an Arctic Escape Route: The Bellot Strait Expedition
}

\section{Adam Lajeunesse and P. Whitney Lackenbauer}

During the second half of the 1950s, Canadian and American vessels surged into the North American Arctic to establish military installations and to chart northern waters. This article narrates the expeditions by the eastern and western units of the Bellot Strait hydrographic survey group in 1957, explaining how these "modern explorers" grappled with unpredictable ice conditions, weather, and extreme isolation to chart a usable Northwest Passage for deepdraft ships. The story also serves as a reminder of the enduring history of US Coast Guard and Navy operations in Canada's Arctic waters in collaboration with their Canadian counterparts.

Au cours de la deuxième moitié des années 1950, des navires canadiens et américains ont envahi l'Arctique nord-américain pour $y$ établir des installations militaires et cartographier les eaux du Nord. Le présent article traite des expéditions des unités est et ouest du groupe de levés hydrographiques du détroit de Bellot en 1957 et explique comment ces " explorateurs modernes 》 ont été confrontés à des états de glace imprévisibles, à des conditions météorologiques et à un isolement extrême en traçant un passage du Nord-Ouest utilisable pour les navires à forts tirants d'eau. Le récit nous rappelle également l'histoire durable des opérations de la Garde côtière et de la Marine américaines dans les eaux arctiques du Canada en collaboration avec leurs homologues canadiens.

In 1957, the construction of the Distant Early Warning (DEW) Line string of Arctic radar stations entered its third season and the US Military Sea Transportation Service (MSTS) - which had been created eight years earlier to control, operate, and administer ocean transportation for the American military services - prepared

The Northern Mariner/Le marin du nord 31, no. 1 (Spring 2021): 1-30 
to send its convoys of supply vessels into Canadian waters to finish the project. ${ }^{1}$ Operating these icebreaking and construction fleets over the past two seasons had proven a crash course in Arctic operations, accelerating the US Navy (USN) and Coast Guard's (USCG) learning curve and bringing into focus many of the dangers involved in operating large numbers of thin-skinned ships in the waters of the Canadian Arctic Archipelago. The MSTS inherited one persistent worry from past Arctic enterprises, extending as far back as the whaling fleets and Victorian explorers of the nineteenth century: the prospect of being trapped by the ice as the region froze back up in the fall.

In the eastern Canadian Arctic, cargo ships had access to a reasonably reliable gateway through Lancaster Sound and Baffin Bay into the Atlantic Ocean. These were some of the last areas of the Arctic to ice up in the fall, with parts of Baffin Bay still navigable well into November. In the western Canadian Arctic, entering and exiting the region was a more precarious proposition. Ships moving east over the top of Alaska into Canadian waters had to pass between the Beaufort Sea icepack and the coastal area surrounding Point Barrow. In the summer months, the ice receded from the coast, allowing ships to pass along a narrow but navigable waterway between Alaska and the permanent pack-ice farther north - a tenuous route at best. During the 1955 and 1956 DEW Line sealifts, difficult ice conditions and strong currents repeatedly closed this escape route on the MSTS fleet as it tried to exit west. In his 1955 report to the Navy, the commander of Amphibious Group Three (the task force assigned to sealift material to the central DEW Line stations), Rear Admiral G.C. Towner, noted that calling the north Alaska coast a "route" was a misnomer, given that it was never open in any "ordinary sense." Icebreakers were repeatedly beset, cargo vessels suffered heavy damage and schedules were impossible to maintain as the ice crashed south into the shore, only then to recede, "like the opening and closing of a series of doors."

For the ships operating east of Point Barrow, failure to slip through that door before it closed for the winter meant being crushed by the ice or, in the best-case scenario, being trapped until the next season's thaw. Relying on luck to preserve dozens of vessels carrying hundreds of crew members and service personnel was poor policy and, beginning in 1956, the US Navy started to examine potential escape routes to the east. ${ }^{3}$ Finding reliable routes was no less important to modern vessels than it had been to previous generations of explorers and whalers.

While narratives surrounding Arctic exploration during the so-called "heroic age" of the nineteenth and early twentieth centuries are plentiful, there is comparatively little scholarship on modern exploration during and after the Second World War. Nevertheless, Canadian and American planners, backed by scientific

\footnotetext{
1 On the MSTS, see Salvatore Mercogliano, "Sealift: The Evolution of American Military Sea Transportation" (PhD diss., University of Alabama, 2004).

2 Cmmdr, Amphibious Group Three, “CTG 5.1: Operational Report Project 572, 1955, "Waldo K. Lyon Papers, Naval History and Heritage Command (NHH).

US Navy, "Post Operation Report: MSTS Arctic Operations" (1957).
} 
research programs, icebreakers, airplanes, and complex logistical systems, set out to understand and master this "hostile environment" in the interests of science and continental defence during this period. ${ }^{4}$ The postwar naval and coast guard task forces that operated in the region faced age-old environmental challenges associated with unpredictable ice conditions, weather, and extreme isolation. Over time, the size and scope of Arctic convoys grew, requiring innovative planning, elaborate preparations, and complex joint (Canada-US) interdepartmental/interagency coordination. These "modern voyages" of exploration made an expanded security footprint in the Arctic possible and facilitated the establishment and sustainment of stations in parts of the Arctic that were hitherto inaccessible to non-Indigenous people, culminating with the construction of the DEW Line. ${ }^{5}$

This article narrates the difficulties experienced by the eastern and western units of the Bellot Strait survey group created in 1957 to chart a usable Northwest Passage for deep-draft ships, advance hydrographic sounding efforts, and mark the route with aids to navigation. While historian P.J. Capelotti and retired Coast Guardsman Dick Judge have chronicled the details of this historic operation, the academic community has largely overlooked it. ${ }^{6}$ The role of the Canadian icebreaker HMCS Labrador has similarly received only passing reference. ${ }^{7}$ Drawing on the work of Capelotti and Judge, we use records from American and Canadian archives as well as private letter collections and diaries to incorporate US Coast Guard and Royal Canadian Navy perspectives, revealing how the North American partners overcame environmental challenges to achieve the first "triple feat of circumnavigation" and the first hydrographic survey of narrow, swift-

4 Matthew Farish, "Frontier engineering: from the globe to the body in the Cold War Arctic," Canadian Geographer 50, no. 2 (2006): 177-196; and Farish, The Contours of America's Cold War (Minneapolis: University of Minnesota Press, 2010).

5 See for example: Richard Morenus, DEW Line: Distant Early Warning - The Miracle of America's First Line of Defense (New York: Rand McNally, 1957); Daniel Heidt and P. Whitney Lackenbauer, "Sovereignty for Hire: Civilian Contractors and the Distant Early Warning (DEW) Line," in DeIcing Required: The Canadian Air Force's Experience in the Arctic, eds. P.W. Lackenbauer and W.A. March(Trenton: Canadian Forces Air Warfare Centre, 2012), 95-112; and Matthew Farish and P. Whitney Lackenbauer, "Western Electric Turns North: Technicians and the Transformation of the Cold War Arctic," in Ice Blink: Navigating Northern Environmental History, eds. Stephen Bocking and Brad Martin (Calgary: University of Calgary Press, 2016), 259-90; and P. Whitney Lackenbauer and Matt Farish, The Distant Early Warning (DEW) Line Coordinating Committee: Minutes and Progress Reports, 1955-63, Documents on Canadian Arctic Sovereignty and Security (DCASS) no. 15 (Calgary: Arctic Institute of North America, 2019).

$6 \quad$ P.J. Capelotti, Across the Top of the World: The U.S. Coast Guard's 1957 Northwest Passage Expedition (Washington: USGC Historian's Office, 2007); and Dick Judge, The Historic Northwest Passage and the CGC Storis: The Story of a Young Man Growing Up in the Coast Guard in the 1950s (self-published, 2007).

7 P. Whitney Lackenbauer and Elizabeth Elliot-Meisel, eds., "One of the Great Polar Navigators: " Captain T.C. Pullen's Personal Records of Arctic Voyages, Volume 1: Official Roles, DCASS No. 12 (Calgary: Arctic Institute of North America, 2017); and P. Whitney Lackenbauer, Adam Lajeunesse, and Jason Delaney, HMCS Labrador: An Operational History (Antigonish: Mulroney Institute on Government, Arctic Operational History Series, vol. 1, 2017). 
flowing Bellot Strait which separates continental America from the Arctic Islands. The story also serves as a reminder of the enduring history of US Coast Guard and Navy operations in Canada's Arctic waters in collaboration with their Canadian counterparts.

Between the end of the Second World War and the completion of the DEW Line, the US Navy and Coast Guard sent dozens of icebreakers and cargo ships to the waters of the Canadian Arctic Archipelago. Although the US Coast Guard manages the country's icebreaker fleet today, both the Navy and the Coast Guard had icebreakers in the mid-1950s. The Navy operated five polar icebreakers (four Wind-class vessels and the USS Glacier), while the Coast Guard operated three, along with a fleet of light ice-strengthened buoy tenders and other smaller vessels - such as Storis, Spar, and Bramble. Often working together, the Navy and Coast Guard vessels kept shipping lanes open and supported cargo vessel operations in the polar regions. ${ }^{8}$ This combined capacity dramatically outweighed what the Canadian government had to offer and, accordingly, American vessels completed much of the early postwar charting and surveying in the North American Arctic, transported materiel and personnel to establish radar and weather stations, and resupplied Canadian and American forces stationed in the Arctic islands.

Despite persistent Canadian worries about sovereignty, Canadian and US officials applied lessons from missions such as Task Force 80 (1948) to subsequent resupply activities, ensuring a smooth operational relationship into the $1950 \mathrm{~s} .{ }^{9}$ From 1951-52, for example, MSTS ships embarked on Operation Support of North Atlantic Construction (SUNAC) and ventured into the Labrador Sea, Davis Strait, and Baffin Bay to construct radar outposts along Canada's northeastern shore and western Greenland, as well as enlarging the US Air Force base at Thule (Operation Blue Jay). Crews honed their skills in a challenging operational environment and, even with the benefit of "modern" technology, ships frequently sustained damage during these voyages and captains begrudgingly accepted that they had to adapt or yield to environmental conditions. ${ }^{10}$

A changing strategic threat environment prompted a dramatic heightening of tempo in North American Arctic operations in the 1950s. The Soviet-backed invasion of South Korea and the USSR's development of the hydrogen bomb and the long-range aircraft required to drop these warheads on North American cities - amplified American concerns about Soviet intentions and capabilities. The US response was to establish a network of early warning radar stations stretching across the North American Arctic from Alaska to Greenland. The DEW Line

\footnotetext{
8 The USN icebreakers were transferred to the USCG between 1965 and 1966. See Peter Kikkert, "'The United States Cannot Afford to Lag Behind Russia': Making the Case for an American Nuclear Icebreaker, 1957-1961," The Northern Mariner 31, no. 1 (2021): 30-60.

$9 \quad$ See Peter Kikkert and P. Whitney Lackenbauer, "Setting an Arctic Course: Task Force 80 and Canadian Control in the Arctic, 1948," The Northern Mariner 21, no. 4 (2011): 327-58.

10 Daniel Heidt and P. Whitney Lackenbauer, The Joint Arctic Weather Stations: Science and Sovereignty in the High Arctic, 1946-72 (Calgary: University of Calgary Press, forthcoming 2021).
} 
was designed to give American bombers enough notice to launch in the case of a Soviet attack, thus keeping the country's response capacity (and, by extension, deterrence) intact.

Paid for and constructed by the United States, the DEW line involved an extraordinary feat of "geographical engineering, planned and sequenced in minute detail," 11 that fundamentally reshaped Arctic logistics, communications, and ultimately the region's human geographies. ${ }^{12}$ During the construction phase from 1955-57, the MSTS moved over 460,000 tons of equipment and supplies into the Canadian Arctic, including enough gravel to build two copies of the Great Pyramid of Giza. " ${ }^{13}$ "Stretching for 2,500 miles across the Arctic, it required the biggest taskforce of ships since the invasion of Europe and the largest air operation since the Berlin airlift to take in the supplies," Canadian Department of Northern Affairs and National Resources official Charles Marshall trumpeted in a 1957 magazine article. "More than 7,000 men laboured through two short Arctic construction seasons to complete the work on schedule. Small wonder that many consider the project one of the most dramatic engineering achievements of our time and a milestone in the development of the Arctic." 14

Although Canadian and American officials had already established solid working relationships that facilitated the cooperative shipment of thousands of tonnes of materiel to isolated stretches of Arctic coastline, these North American Arctic operations resurrected Canadian sensitivities about sovereignty. The US acknowledged Canadian terrestrial sovereignty over the islands of the Arctic Archipelago but the escalating tempo and scale of maritime activities in the waters between the islands raised questions about control over practical activities therein. ${ }^{15}$ Creative diplomacy and mutual accommodation ultimately prevailed, but senior Canadian decision makers offered frequent pledges to "Canadianize" Arctic operations and "keep the Canadian Arctic Canadian."16 Canada's limited

11 Farish, The Contours of America's Cold War, 184.

12 Mercogliano, "Sealift: The Evolution of American Military Sea Transportation."

13 Western Electric, The DEW Line Story (c.1960).

14 C.J. Marshall, "North America's Distant Early Warning Line," Geographical Magazine 29:12 (1957), 616.

15 See, for example, Donat Pharand, Canada's Arctic Waters in International Law (Cambridge: Cambridge University Press, 1988); Elizabeth Elliot-Meisel, Arctic Diplomacy: Canada and the United States in the Northwest Passage (New York: Peter Land, 1998); P. Whitney Lackenbauer and Peter Kikkert, "Sovereignty and Security: The Department of External Affairs, the United States, and Arctic Sovereignty, 1945-68," in In the National Interest: Canadian Foreign Policy and the Department of Foreign Affairs and International Trade, 1909-2009, eds. Greg Donaghy and Michael Carroll (Calgary: University of Calgary Press, 2011), 101-20; Adam Lajeunesse, Lock, Stock, and Icebergs: The Evolution of Canada's Arctic Maritime Sovereignty (Vancouver: UBC Press, 2016); and Adam Lajeunesse, "A Gentleman's Agreement: Sovereignty, Defence and Canadian-American Diplomacy in the Arctic," in Breaking Through: Understanding Sovereignty and Security in the Circumpolar Arctic, eds. Wilfrid Greaves and P. Whitney Lackenbauer (Toronto: University of Toronto Press, 2021), 45-61.

16 Advisory Committee on Northern Development (ACND) meeting minutes, 10 March 1949, in P. 
icebreaking capacity and prioritization of operations in Hudson Bay and the St. Lawrence and Saguenay Rivers meant that its resources were always limited. As such, it continued to rely on the Americans to shoulder the brunt of the Arctic operational burden in the early 1950s. ${ }^{17}$ The archival record demonstrates that there was no insidious plot by the US Navy or Coast Guard to monopolize the sealift supporting the Joint Arctic Weather Stations and no nefarious intent to build a rival claim to sovereignty over the High Arctic islands. Instead, American officials eagerly awaited new Canadian capacity that would contribute substantively to resupply efforts. ${ }^{18}$ The commissioning of the upgraded Wind-class icebreaker HMCS Labrador into the Royal Canadian Navy in July 1954 thus represented a powerful instrument offering much-welcomed capacity to contribute to joint Arctic construction projects. ${ }^{19}$

From the onset, HMCS Labrador's operators gave less thought to questions of sovereignty and jurisdiction than to practical considerations of navigation. The DEW Line mission required that she partake "in one of the greatest seaborne operations ever attempted in the Far North," the RCN service magazine Crowsnest informed its readers at the time. The ship's "principal and most testing assignment" in 1955 was to serve from mid-June through September "as senior ship of a task group of some fourteen ships charged with the delivery of thousands of tons of supplies to build DEW Line sites in the Foxe Basin area of the Eastern Arctic." This meant delivering personnel, equipment, and supplies, as well as completing "numerous other associated tasks requiring a high degree of operational efficiency and an equivalent amount of effort." These included "the survey of previously uncharted waters, selection and survey of landing sites, installation of navigational control stations and, most important, the safe passage, through hazardous, iceinfested seas, of the ships comprising the Task Group." ${ }^{20}$

Labrador completed all its tasks but operating in the Arctic Archipelago remained a dangerous proposition. During the 1955 sealift into the western Arctic, for instance, five ships lost or damaged their anchors, fourteen lost or damaged rudders, there were thirteen groundings, twenty-two instances of damaged propellers and shafts, forty-three electrical casualties, forty-four ships with hull

\footnotetext{
Whitney Lackenbauer and Daniel Heidt, eds., The Advisory Committee on Northern Development: Context and Meeting Minutes, 1948-66, Documents on Canadian Arctic Sovereignty and Security (DCASS) No. 4 (Calgary: Arctic Institute of North America, 2015), 117.

17 G.L. Magann to William Snow, 14 March 1949, RG 59, entry 1177, PJBD Subject Files, 1940-59, box 5, f. PJBD-General, 1948-56, National Archives and Records Administration (NARA).

18 Office of the Chief of Naval Operations to Dr. Reichelderfer, 30 September 1949, RG 27, entry 5, box 3, f. 'Arctic Operations, 1950,' NARA.

19 On the history of HMCS Labrador, see John Leeming, "HMCS Labrador and the Canadian Arctic," in RCN in Retrospect, ed. James Boutilier (Vancouver: UBC Press, 1982), 286-307.

20 "The Labrador and the DEW Line," Crowsnest 8, no. 3 (1956), reprinted in Adam Lajeunesse and P. Whitney Lackenbauer, eds., Canadian Armed Forces Arctic Operations, 1945-2015: Historical and Contemporary Lessons Learned (Fredericton: Gregg Centre for the Study of War and Society, 2017), 184.
} 
damage, and twenty-eight cases of "miscellaneous" damage. On average, two US ships sustained damage each day. ${ }^{21}$

The shared mission of running task groups to build the DEW Line and execute what was described at the time as "probably the greatest single construction order in history" 22 proved daunting. Shepherding and then landing enormous loads of construction equipment and material by landing craft over Arctic beaches, after first charting and clearing the approaches, posed enormous challenges. "The work was not glamorous or adventurous," Captain Owen Robertson explained about Labrador's Arctic voyages. "Most of it was just plain hard work, long-hours, bad weather and monotony; but we did know that what we were doing was important to Canada - that was our reward." ${ }^{23}$ Conducting preliminary reconnaissance of unknown waters, surveying new routes, charting beaches and anchorages, undertaking scientific research, or carrying out rescue operations entailed adaptability in the face of uncertainty, and ice convoy work could be strenuous and dangerous. These operations yielded valuable lessons that informed future convoy operations and Arctic navigation more broadly. ${ }^{24}$

During the summer of 1956, Labrador's primary task was assisting with the sea supply of the DEW Line stations in the eastern Arctic. The captain of the Department of Transport patrol ship C.D. Howe, sitting comfortably off Coral Harbour, was reputed to have said that "because ice conditions were so bad this year the sealift ships would never get through and that Labrador would not make it either," RCN Captain Thomas C. Pullen noted on 1 August. "Well, here we are! Silly old man." After erecting beacons in Foxe Basin, Labrador joined the US Navy icebreaker Edisto to convoy supply ships to the DEW Line sites. Operating in largely uncharted waters, they began a hydrographic survey of Fury \& Hecla Strait, a welcome "break from the flat monotony of Foxe Basin, rocky and interesting," as Pullen recorded on 16 September. ${ }^{25}$ Subsequently, Labrador made four attempts to push through Bellot Strait but each time encountered waters shoaled to within twenty feet of the bottom of the ship. In discovering a deep channel on the side of the channel, Labrador also identified "Magpie Rock" in the middle - a menacing obstacle "over which the water is boiling and frothing at six to eight knots, maybe ten." ${ }^{26}$ When Pullen and Labrador docked in Halifax on 13 October, the captain took stock of his achievements: "103 days away, 100 days at sea, ... steamed

\footnotetext{
21 Commander, MSTS to Chief of Naval Operations, "MSTS Arctic Operations 1955," 15 February 1955, RG 313, entry UD-13C 11, box 5, NARA.

22 Morenus, DEW Line, quoted in Farish, Contours of America's Cold War, 185.

23 O.C.S. Robertson, "Foreword" to T.A. Irvine, The Ice was All Between Us (Toronto: Longmans Green, 1959), xxii.

24 See Lackenbauer, Lajeunesse, and Delaney, HMCS Labrador, and Lackenbauer and ElliotMeisel, "One of the Great Polar Navigators."

25 Pullen diary, 16 September 1956, in Lackenbauer and Elliot-Meisel, "One of the Great Polar Navigators."

26 Pullen diary, 25 September 1956, in Lackenbauer and Elliot-Meisel, "One of the Great Polar Navigators."
} 
18,606 miles, approximately 12,000 of which were in uncharted waters. Had several close calls - the worst occurring in Foxe Basin when we were within seven feet of taking the ground off the southwest corner of Rowley Island, and in Bellot Strait when prudence kept us from attempting a passage." ${ }^{27}$ Confirming an eastern outlet through Bellot Strait, which would provide an alternative for the western convoys if their northern Alaskan route became unnavigable, remained imperative.

Aerial surveys flown in 1956 showed a potentially navigable passage south of Victoria Island, up Franklin Strait, and through the uncharted Bellot Strait. The route had potential. If ice in the Beaufort Sea closed that path to shipping then, theoretically, ships might be able to travel through the Arctic Islands to exit through Baffin Bay or Hudson Strait. On a map this looked like an easy alternative. Despite years of charting, however, the hydrography of this route and its hidden dangers - remained relatively unknown. USCG cutter Storis and USS Requisite (a repurposed minesweeper) had spent the 1955 and 1956 seasons charting the western half of this route: Amundsen Gulf to Dolphin and Union Strait, Coronation Gulf, and Queen Maud Gulf. At the end of the 1956 expedition, these ships requested permission to continue towards Bellot Strait, but the chief of MSTS denied it, asserting that the mission was impracticable (particularly for thin-skinned Requisite). The route from Queen Maud Gulf to Bellot Strait was shallow, uncharted, and dangerous; only small, shallow-draft vessels had traversed this route historically. ${ }^{28}$ To be considered viable for American supply vessels and icebreakers, a passage with at least a 35-foot draft needed to be found, charted, and marked with navigational aids. ${ }^{29}$

In early 1957, the new MSTS chief made the passage a priority and formed a Bellot Strait survey group labelled Task Group 6.5. This group was split in two: Captain Thomas Pullen commanded the East Unit (TG 6.5.0), comprised of HMCS Labrador; while USCG Captain Harold L. Wood commanded the West Unit (TG 6.5.1) comprising USCGC Storis, Spar, and Bramble. The plan was for Labrador to retry the eastern approaches to Bellot Strait and, once there, meet up with Storis, Spar, and Bramble coming from Alaska to chart the western approaches through Queen Maud Gulf and Simpson Strain, Rae Strait, and James Ross Strait. ${ }^{30}$ The lion's share of the work fell to the three US Coast Guard vessels, which had to chop through over 1,800 miles of ice, sounding and mapping the area from Point Barrow to the eastern Arctic.

Tasked with moving through thousands of miles of uncharted and dangerous waters, none of the three US Coast Guard ships had heavy icebreaking capability.

\footnotetext{
27 Pullen diary, 13 October 1956, in Lackenbauer and Elliot-Meisel, "One of the Great Polar Navigators."

28 US Navy Photographic Center, "US Navy Photographic Report (Newsreel): MSTS Operations 1957" (1958).

${ }^{29}$ Excerpts from the Journal and Letters of Captain Harold L. Wood, USCG; provided to authors by the Wood family.

30 US Navy, MSTS Post Operation Report (1957).
} 
Storis had spent the past two years charting the region with Requisite but it was only classified as a light icebreaker. Built in 1941 for service in the easier waters around Greenland, the ship was originally supposed to be named Eskimo, though that was changed after the State Department feared the term (which means eaters of raw meat) would be offensive to the Greenlandic Inuit. Instead, the ship was given a Scandinavian name commonly taken to mean "great ice." 31 Spar and Bramble were both ice-strengthened buoy tenders, built in 1944 with ice-belts at their waterlines. What the three ships lacked was the horsepower of purpose build icebreakers. Working in waters choked with ice, an icebreaker requires the horsepower to back-up and ram ice repeatedly. At 1,200 horsepower, the engines on both Bramble and Spar were not powerful enough to escape heavy ice. Storis' 1,800 shaft horsepower ( $\mathrm{sh}$ ) engines were stronger but still only appropriate for the light ice more commonly found off southern Greenland. To put the ship's capabilities into perspective, the Wind-class cutters boasted 12,000 shp, while the modern Polar class is equipped with 18,000 shp engines. Yet, despite the importance of the operation, the three light ships were all that the US could spare since its heavy icebreakers were committed to escorting DEW Line convoys and resupplying the joint bases scattered across the eastern Arctic.

Preparations for the operation began in early in 1957 and naval officials made every effort to strengthen the ships for the trial ahead. Installing additional steel ice-belts at and below the water line on the hulls of both Spar and Bramble would protect them from ice as well as uncharted pinnacles and dangerous rock formations in the shallow waters of the Canadian Arctic. After years of losing propeller blades in the North, the US Navy and Coast Guard had enhanced their designs to better withstand the ice, and a new stainless-steel propeller on Bramble replaced its bronze screw. New equipment loaded onto the ships included an evaporator for producing freshwater and an early type of side scanning sonar called a Honeywell unit. The ships also had six months of Arctic stores, including 3,000 new books added to combat the boredom and fatigue common on Arctic cruises. ${ }^{32}$

News of the operation began to leak out in the middle of May when Storis suddenly returned to her homeport of Juneau, Alaska, in the middle of a cruise. There, the Coast Guard told the crew to spend time with their families because they might not see them again for six months. Few operations requiring a lighticebreaker required six months to complete, and rumors spread that the ship was going to transit the Northwest Passage. ${ }^{33}$ Storis crew member Ken Fisher knew something big was in the works when he was interviewed by a psychologist. For its part, the US Coast Guard had never attempted such an ambitious Arctic cruise before; not only would it be long and difficult but there was a distinct possibility that the ships would be stuck in the region for the winter. As such, the Coast Guard wanted to make sure that the crews were mentally capable and subjected some crew

31 US Coast Guard, “Storis, 1942," US Coast Guard, https:/www.history.uscg.mil/

32 Capelotti, Across the Top of the World, 12.

33 Capelotti, Across the Top of the World, 10. 
members to a brief psychological interview as part of a general health assessment. ${ }^{34}$ Members of the news media, captivated by the prospect of an American squadron making the fabled Northwest Passage, bombarded the Coast Guard with requests for interviews, tours, and even permission to accompany the ships. "The brass hats are lining up like crows, in Washington, waiting for a chance to climb on board," Captain Wood wrote to his wife. "Send me my bottle of chlorophyll Aspirin ... I'll need it!" 35

On 19 May, Spar left its home port of Bristol, Rhode Island, for Panama. One week later, its sister ship Bramble departed Miami to rendezvous with Spar in the Panama Canal Zone. Continuing along the western coast of the United States, the two vessels reached Seattle on the morning of 27 June and moored alongside Storis, which herself had just arrived from Ketchikan, Alaska, to have a helicopter landing platform installed on the deck. ${ }^{36}$ On 1 July, after taking on final supplies, the three ships departed as a group for the Arctic.

Moving north across the Gulf of Alaska to the Bering Strait, the squadron enjoyed good weather. The transit into the Bering Sea and the Arctic beyond was a long one, however, and the crew had little to occupy their time in these ice-free waters. A beard-growing contest on Storis provided limited amusement. After a week at sea, the Gulf of Alaska became rough and life aboard the three small ships became increasingly uncomfortable - a state of affairs, crew member Dick Judge remembers, that the men's increasingly itchy faces only worsened. ${ }^{37}$

Passing Big Diomede Island, the closest Russian territory to Alaska, broke the monotony on 10 July. When radar aboard Storis indicated Soviet fighter aircraft approaching the squadron from the west, the ship was called to general quarters and the crew manned the ship's guns. Fortunately, the alert proved false; although Storis was armed with a $25 \mathrm{~mm}$ cannon, depth-charges, and a quad $20 \mathrm{~mm}$ anti-air weapon (enough to make her a threat to enemy shipping in the Second World War), those armaments were insufficient to handle Soviet jet fighters. Passing through waters close to the Soviet Union always heightened tensions - and required vigilance. ${ }^{38}$

The Arctic ice ultimately posed a more acute threat to the vessels than the Soviets. The squadron transited the Alaskan coast without incident and was in Canadian waters by 16 July. Off Cape Perry, Storis rammed a mass of old ice, giving the crew a nasty shock and a worrisome beginning to the trip. The vessels had not even entered the Arctic Archipelago but were already encountering eight feet of ice, which covered the entire entrance to Amundsen Gulf. Other ships already in the western Arctic reported the worst ice conditions that many of the

34 Judge, The Historic Northwest Passage and the CGC Storis, 100-101.

35 P.J. Capelotti, "Fog, Wind, and Ice: Navigating the Northwest Passage," Proceedings 135, no. 2 (February, 2009).

36 Capelotti, "Fog, Wind, and Ice: Navigating the Northwest Passage."

37 Judge, The Historic Northwest Passage, 104.

38 Judge, The Historic Northwest Passage, 107. 


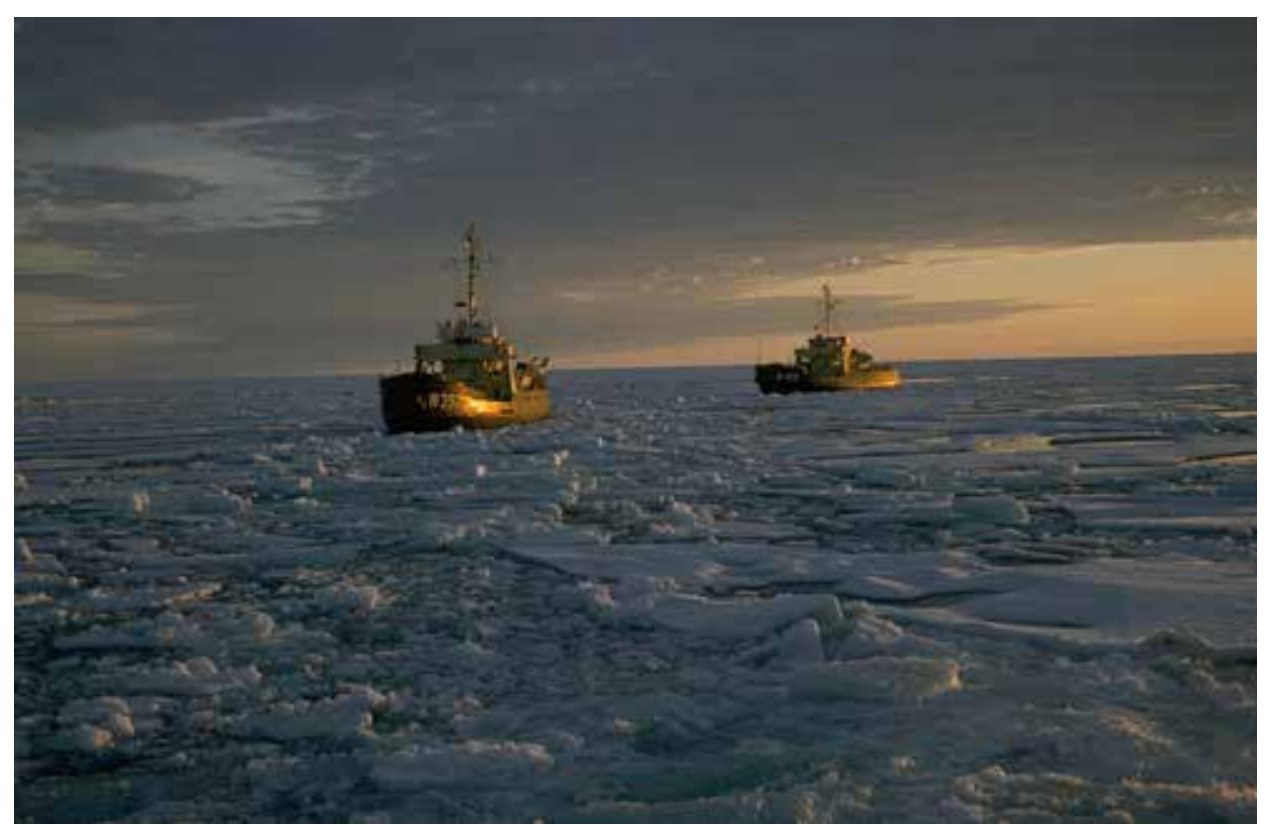

Image 1. USCG Cutter Spar and Bramble in the Northwest Passage. (Image provided by John Hagerty, USCGC Spar Museum)

Arctic veterans had ever experienced. The shipping season had barely begun and already the ice had damaged six transport ships. ${ }^{39}$

Taking advantage of the region's nearly continuous daylight, Storis' two Bell helicopters zipped back and forth looking for leads and scouting the icepack ahead. This information from their airborne scouts enabled the three ships to pick their way through leads in the ice. "Our helicopters are worth their weight in cold cash," Captain Wood wrote in a letter home. ${ }^{40}$ After a week in Amundsen Gulf, the ships arrived at Dolphin and Union Strait, the shallow and sometimes dangerous entrance to the southern leg of the Northwest Passage. Unbroken, thick, winter ice awaited the ships. Again, the helicopters were sent out to look for a way through.

Operating helicopters off the flight deck of a small icebreaker was always a dangerous proposition and on 20 July Storis suffered its first casualty. An attempt to take off by one of the Bells was cut short by the failure of the ground crew to detach one of the tie-downs holding the aircraft to the deck. The strap flipped the helicopter over, sending it tumbling overboard. The plexiglass cockpit shattered and one of the pontoons broke off. Amazingly no one was killed and only the pilot was injured. The helicopter, however, was a total wreck. ${ }^{41}$ Reduced to one aircraft, the squadron found itself in a difficult position since two were needed to meet safety guidelines. Luckily for Storis, the icebreaker USS Burton Island was

39 Capelotti, "Fog, Wind, and Ice."

40 Excerpts from the Journal and Letters of Captain Harold L. Wood.

${ }^{41}$ Excerpts from the Journal and Letters of Captain Harold L. Wood, USCG, 20 July 1957. 
operating nearby in the Beaufort Sea and had a spare that it delivered promptly.

Progress was slow through the thick winter ice in Dolphin and Union Strait and, for several days after the helicopter crash, the ships were beset in the ice. The pressure on the sides of the cutters was "terrific" and held them firmly in place. Ice on the starboard side of the three ships slowly pushed inwards, eventually tipping the vessels up to ten degrees to port. ${ }^{42}$ In an effort to rock themselves free, the crews weighted booms and swung them back and forth. This action proved futile, but when the shifting ice slowly released Spar from its grasp, the ship made painstaking progress to break the ice and release the pressure on the other two ships. The effort ground to a rapid halt when the ice re-trapped the Spar, pushing her over eight degrees and ending the rescue. The gunner's mate aboard Storis attempted to extricate the ship with explosives, but this accomplished little more than a fourfoot-wide hole in the ice. Crewman Judge sarcastically noted that if they could do that 200 more times they might even strike water. ${ }^{43}$ The crew realized that only a change in wind and current would release them. The waiting game, known to so many Arctic expeditions, had begun.

The ever-shifting ice opened modestly on 26 July, allowing the task force to move slowly forward in a column formation for nearly three-quarters of a mile. Although individual ships became stuck the others were able to ride up beside them to release the pressure and maintain forward momentum. The captains of all three ships agreed that their ice-strengthened hulls were important and that the thin-skinned vessels, like USS Requisite, should not be used for such tasks in the future. ${ }^{44}$

The task force was beset once again after it proceeded into Coronation Gulf. The helicopters zipped forward to search for a navigable route, their work supplemented by Canadian ice reconnaissance flights from Cambridge Bay. The situation reached crisis levels on 29 July when Storis rammed an immovable ice floe. Spar, traveling astern, had to slow to avoid a collision. Having lost momentum, the ships sat trapped for two long days while northern winds carried more ice down around them. Ice floes forced their way under Spar, jamming the rudder, tilting the ship by $20^{\circ}$, and pushing it upward and into Storis. Wedged together, the ships' crews were close enough to pass back and forth between the vessels. ${ }^{45}$ To prevent excessive damage, the crews rigged airplane tires as fenders - which the extreme pressure soon flatted into large gaskets. As the two ships scraped against one another, Spar's anchor threatened to pierce Storis' hull and had to be dropped onto the ice to prevent a breach. Storis' crew was surprised to see that the crash of the anchor barely dented the ice. ${ }^{46}$

42 Excerpts from the Journal and Letters of Captain Harold L. Wood, USCG, 20 July 1957.

43 Judge, The Historic Northwest Passage, 130.

44 Excerpts from the Journal and Letters of Captain Harold L. Wood, 26 July 1957.

45 Capelotti, Across the Top of the World, 14.

46 Excerpts from the Journal and Letters of Captain Harold L. Wood, 24 July 1957. 


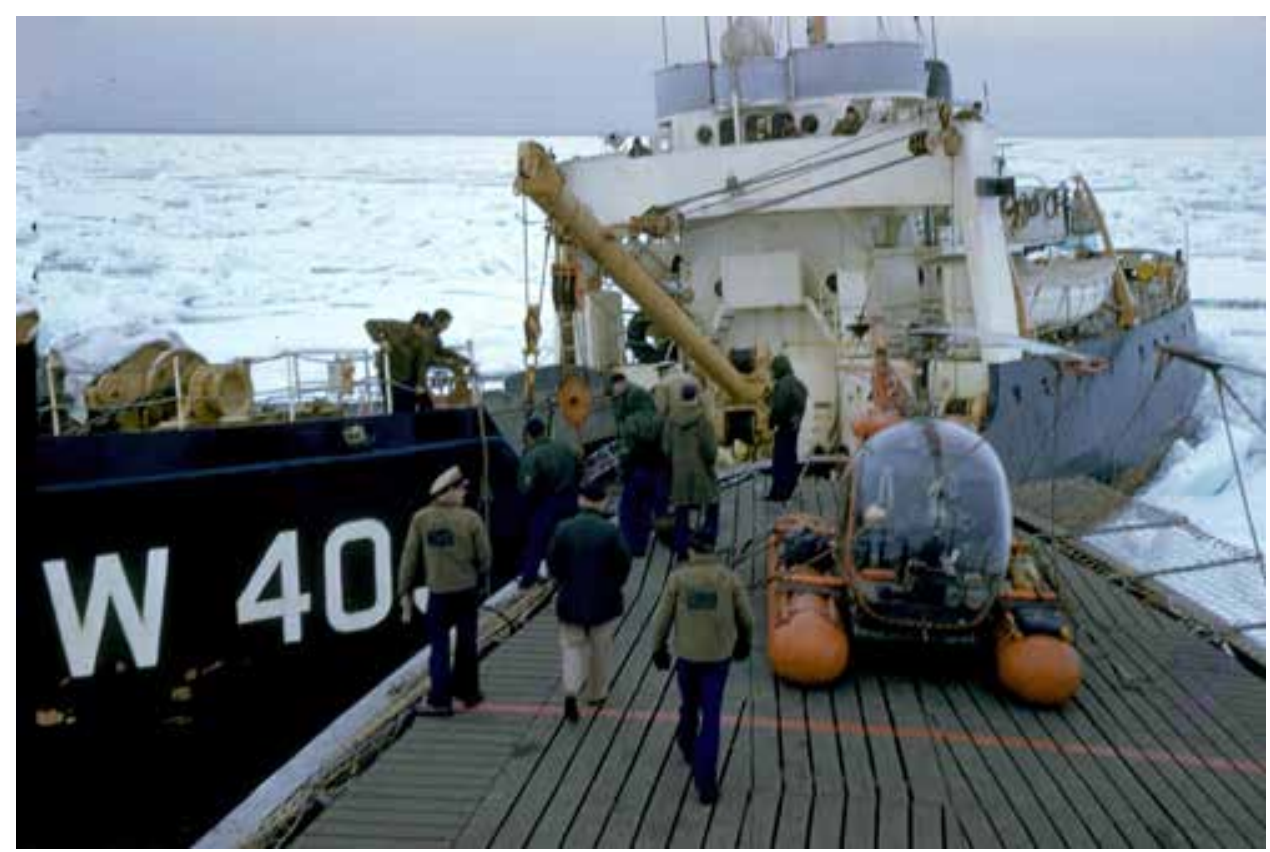

Image 2. USCGC Spar driven by the ice into USCGC Storis. (Image provided by John Hagerty, USCGC Spar Museum)

The ice pushed the ships south towards the coast until they were only 700 yards away from dry land, with a mere 14 feet between their hulls and the seabed below. On the beach, the crews could see the floes pushing inwards and piling up, creating a pile of jagged, rock hard ice 50-feet high. Damage control teams patrolled the ships with emergency equipment, expecting punctures at any moment. The ice pressure lifted Storis nine feet above the waterline, making her entire propeller visible to the crew of Spar - who could at least confirm that the blades were in good shape. ${ }^{47}$

Amongst the crew, rumours began to circulate that the ships would be stuck in the Arctic for the year and that the Coast Guard would soon start removing men to Edmonton, leaving behind only a skeleton crew to maintain the ships. "We were stuck," recalled Jim Loback, a petty officer on board Storis, "and there were rumors that they were going to start taking people off." 48 By this point, crew members assumed that there was now no water at all beneath the ship. All the three vessels could do, Captain Wood noted, was "sweat it out." The Coast Guard cutters had little choice but to wait patiently. On the third day, however, the pressure began to ease and Storis and Spar dropped into liquid water, managing to push towards Bramble which was still beset five miles away. Once reunited, the task group followed what Wood called a "tortuous lead" north for twenty-one miles where

47 Excerpts from the Journal and Letters of Captain Harold L. Wood, 30 July 1957.

48 Capelotti, "Fog, Wind, and Ice." 
they came to the edge of the ice, almost at the shore of Victoria Island. ${ }^{49}$ The task force had travelled roughly 340 miles into the Canadian Arctic Archipelago and still had to cover 600 miles to get to Bellot Strait.

Proceeding through Dolphin and Union Strait, the ships enjoyed improving conditions and focused on tasks unrelated to immediate survival. In Coronation Gulf they surveyed a previously uncharted island and took soundings. On 5 August they entered Dease Strait, still feeling their way through small leads and cracks in the ice near the shoreline of Victoria Island. The next day the task force arrived at Cambridge Bay, a small Inuit settlement with a DEW Line station and an RCMP detachment. The crew was granted a brief shore leave but walking on the rough terrain inspired little excitement. The Hudson's Bay Company store had no furs or Inuit art for sale, and Wood noted that the sparsely stocked shelves contained nothing that the crew could not buy down south at Sears for one third the price. ${ }^{50}$ Bramble broke the ice in the bay and the force sounded the area to improve charts for the MSTS supply ships that were due later in the season. Divers also went below to inspect the hulls and noted that the weeks of hard icebreaking had actually caused minimal damage. A four-foot section of Bramble's port bilge keel was badly dented and Spar's propeller had been damaged, but both ships could push on. ${ }^{51}$

The brief encounter with Inuit at Cambridge Bay affirmed that the waters through which the vessels sailed formed part of Inuit Nunangat - the Inuit homeland in Canada. Located on the southeast coast of Victoria Island, Ikaluktutiak ("the fair fishing place" in Inuinnaqtun) had been a hub for Inuit activity since time immemorial. In 1839, Hudson's Bay Company explorers Peter Warren Dease and Thomas Simpson had crossed over the Dease Strait and named Cambridge Bay after the Duke of Cambridge, a patron of science and exploration. Richard Collinson and the crew of the HMS Enterprise became the first Europeans to winter in the bay in 1852 when he extolled the resourcefulness, hardiness, and cheerfulness of Inuinnait. But these explorers - like the American crews in the 1950s - did not draw substantively upon Inuit Qaujimajatuqangit (Indigenous knowledge) to facilitate their exploration. Diamond Jenness recorded a vast amount of information about Inuinnait societies during the Canadian Arctic Expedition (1914-1917), the Kitikmeot soon became known as one of the best fox-fur producing regions in the Arctic, and the Royal Canadian Mounted Police and then Anglican missionaries established a regional presence in the 1920s. The RCMP's famous patrol vessel, St. Roch, often over-wintered in the bay and occasionally provided transportation to traveling Inuinnait. Nevertheless, none of the MSTS planners or ships' captains capitalized on local knowledge in 1957 when passing through Inuit Nunangat - a telling statement about their faith in modern technology and dismissal of Indigenous knowledge and ways of knowing. ${ }^{52}$

49 Excerpts from the Journal and Letters of Captain Harold L. Wood.

50 Excerpts from the Journal and Letters of Captain Harold L. Wood, 9 August 1957.

51 Capelotti, Across the Top of the World, 16.

52 For a brief history of the community, see Peter Kikkert and P. Whitney Lackenbauer, "A History of 
From Cambridge Bay the task force enjoyed a comparatively easy passage east through Queen Maud Gulf. One of the more dangerous areas of the Arctic Archipelago to navigate, this area is fraught with shoals and subject to rapid changes in current and wind that draw ice down from McClintock Channel and can push ships against the coast. Thankfully, calm conditions prevailed, and the ships set to work erecting shore aids and charting safe routes for cargo ships, taking miles of soundings in the ensuing weeks - a routine task made difficult by the still constant fog and shifting ice conditions. The ships accelerated the pace when they learned that the MSTS convoys had entered the Arctic and were en route to Queen Maud Gulf. In a letter home, Captain Wood explained that his philosophy was to "wait until the ice is out of the way!" While fine in theory, he noted that the Coast Guard hardly subscribed to it in practice. "I was my own boss, as far as the final decision concerning running of the survey was concerned, but I didn't control the advance of the re-supply units, and they were rapidly overtaking us." In addition to the survey work, the task force had a gentlemen's agreement to assist the re-supply convoys. Time was pressing and many shore radar-reflectors and aids to navigation needed to be installed before the supply ships arrived..$^{53}$

Simpson Strait is a narrow, dangerous passage separating King William Island from the Canadian mainland. Surveying the area before the arrival of the MSTS convoy, Storis grounded on 14 August. Although the ship's charts showed the area to be clear, it ran onto a previously unmarked shoal. In order to extricate itself, the cutter waited for the tide to raise the water level by nine inches and, when it did, Storis managed to pull off without tearing its hull. ${ }^{54}$ Divers were immediately sent below to inspect the damage and found a bilge keel torn back from the hull "like an opened sardine can." 55 Thankfully, the tear did not compromise the integrity of the hull and the ship proceeded under its own power back into Queen Maud Gulf.

By the middle of August, the supply ships arrived in the Gulf and exchanged mail and movies with the small Coast Guard fleet for several days while resupplying the task force. ${ }^{56}$ Storis, meanwhile, rendezvoused with the Navy's salvage tug USS Grapple, which dispatched its own divers to seal the remaining bilge. ${ }^{57}$ With the work completed, Storis returned to Simpson Strait and safely escorted a convoy which unloaded its cargo at Gjoa Haven. The markers and charting established by the task force allowed for an easy mission for the MSTS ships, which completed

\footnotetext{
Ikaluktuuttiaq," in A Guidebook for Research with Nunavut Communities, Iqaluktuuttiaq (Cambridge Bay) Edition (Cambridge Bay, NU: Polar Knowledge Canada/Pitquhirnikkut Ilihautiniq, 2016), 1431. On perceptions of what the DEW Line meant for Inuit at the time, see Lackenbauer, "At the Crossroads of Militarism and Modernization: Inuit-Military Relations in the Cold War Arctic," in Roots of Entanglement: Essays in Native-Newcomer Relations, eds. Myra Rutherdale, Lackenbauer, and Kerry Abel (Toronto: University of Toronto Press, 2018), 116-58.

53 Excerpts from the Journal and Letters of Captain Harold L. Wood, 8 September 1957.

54 Excerpts from the Journal and Letters of Captain Harold L. Wood, 14 August 1957.

55 Judge, The Historic Northwest Passage, 153.

56 Capelotti, Across the Top of the World, 18.

57 Judge, The Historic Northwest Passage, 153.
} 
their work and soon proceeded safely westward towards Alaska.

While the three US Coast Guard vessels struggled through the Central Arctic, HMCS Labrador approached from the east. For Canada, and for Captain Pullen in particular, charting the strait had a significance beyond the operational requirements created by the DEW Line. If Bellot Strait could be opened, it would represent a new link in the Northwest Passage - a route that had fired the British imagination for generations. The Arctic had brought the Pullen family particular fame, beginning with the Labrador captain's great-uncle. Commander (later Vice Admiral) W.J.S. Pullen commanded the depot ship North Star on the 1852-54 Belcher expedition to find Franklin, with his younger brother T.C. Pullen (later Captain) as his second-in-command. ${ }^{58}$ Thanks to their exploits, when Tom Pullen sailed in the Arctic a century later, "there were four Pullen place-names to remind him of his great-uncles." ${ }^{59}$

In 1880, when Canada inherited the British Empire's remaining Arctic holdings, it incorporated this distant realm into its identity as a northern nation. ${ }^{60}$ Practical action to administer and develop the region, however, was limited. The searches from Franklin had proven that the Northwest Passage offered no viable route to "the Orient." Norwegian explorer Roald Amundsen transited the Passage from 1903-06 but this feat was not repeated until Henry Larsen's transits in the RCMP schooner St. Roch in 1940 and 1942. ${ }^{61}$ Although Royal Canadian Navy personnel had participated in the dangerous "Murmansk Run" from Britain to Russia and plied convoy Arctic routes close to Iceland and Greenland during the Second World War, no RCN warship ventured into the region until HMCS Magnificent, Haida and Nootka undertook operations in Hudson Bay in 1948 and HMCS Cedarwood traveled into the western Arctic the following year. All were brief excursions by thin-skinned vessels. ${ }^{62}$ For reasons of national pride, officials wanted a more

\footnotetext{
58 David Maclellan, "Pullen of the Arctic," Canadian Geographic 104, no. 2 (1984).

59 Captain Tom Pullen obit, Daily Telegraph [London], clipping provided by the Pullen family.

60 See for example: Shelagh D. Grant, "Myths of the North in the Canadian Ethos," Northern Review 3, no. 4 (1990):15-41; Renée Hulan, Northern Experience and the Myths of Canadian Culture (Montreal \& Kingston: McGill-Queen's University Press, 2001), 3-28; Kerry Abel and Ken Coates, "The North and the Nation," in Northern Visions: New Perspectives on the North in Canadian History, eds. Abel and Coates (Peterborough: Broadview, 2001), 1-21; and Ken Coates, P. Whitney Lackenbauer, Bill Morrison, and Greg Poelzer, Arctic Front: Defending Canada in the Far North (Toronto: Thomas Allen, 2008).

${ }^{61}$ RCMP officer Bill White suggests that Larsen's achievement was preceded by other Canadian ships. White alleges that "the so-called Northwest Passage was a busy bloody highway by this time with trading posts all along it and supply ships like the Chimo and the Aklavik going this way and that way every year. Not too many crossed through from west to east, but I know the Aklavik did it in 1938 and Henry [Larsen] knew it too." Patrick White, Mountie in Mukluks: The Arctic Adventures of Bill White (Madeira Park, BC: Harbour Publishing, 2004), 227-28.

62 W.A.B. Douglas, Roger Sarty, and Michael Whitby, A Blue Water Navy: The Official Operational History of the Royal Canadian Navy in the Second World War, 1943-1945, Volume II, Part 2 (St. Catharines: Vanwell Publishing, 2007); Isabel Campbell, "Making a Difference in Arctic Naval Research, HMCS Cedarwood, 1948-1956," Canadian Naval Review 8, no. 1 (Spring 2012): 1014; Michael Whitby, "Deployments by Ships of the Royal Canadian Navy into Canadian Northern
} 
permanent Canadian presence as well as a ship to chart the Northwest Passage. For Pullen, whose ship had been turned back by Bellot Strait the previous season, this offered a chance at redemption.

By late June, when Labrador took on provisions and 8,000 barrels of diesel fuel in Halifax for its upcoming journey, a thousand hours of labour had been invested in overhauling its engines and boilers. Aboard were 226 officers, men, and civilian scientists, as well as a US Navy liaison officer and a team of American reporters and photographers. Most of the ship's compliment was new, as nearly sixty percent of the crew that had reached Bellot Strait in 1956 had been transferred that winter, depriving the ship of some core Arctic experience. ${ }^{63}$ More disconcerting was news, received when Labrador set to sea on 25 June, that USCGC Eastwind had burned out one of her two main motors, thus forcing its return to Boston for repairs. The icebreaker count for the entire eastern Arctic was therefore reduced by twenty-five percent for the season. Supporting the sealift and resupply effort would fall to HMCS Labrador, USS Edisto, and USCGC Westwind. ${ }^{64}$

Heading north, Labrador collected the tankers USS Kankakee and Memphis, waiting off Hamilton Inlet to resupply the USAF's Strategic Air Command base at Goose Bay, before moving into the ice at 4:30 a.m. It was an inauspicious beginning to the operating season. The Canadians were impressed by how well the captain of Kankakee handled his 22,000-ton tanker, which was crewed by the US Navy, by driving it like a destroyer while keeping close and following in Labrador's wake. By contrast, Memphis was a civilian vessel on contract to MSTS and the difference in styles and capabilities were readily apparent. While Kankakee kept in close formation, Memphis continued to lag behind, unable to keep up speed and maintain course. Captain Pullen soon learned that Memphis ruptured a forward tank, spilling 800 barrels of bunker fuel into the pristine sub-Arctic waters. Had Pullen pushed too hard? Did he fail to appreciate the limitations of the thin-skinned tanker that he was responsible for leading? In his report afterwards, Pullen wrote with bitter exasperation that "she had nobody to thank but herself." 65 The captain of Memphis would have told a different story - one more critical of Pullen's harddriving, impatient, even brash style.

That night, Edisto arrived to assist. The last time the two icebreakers had been together was September of 1956 when the American vessel lost one of its

\footnotetext{
Waters, 1949-2014," Canadian Naval Review, Broadsides Forum (November 2014); and Campbell, "A Reassessment of the Royal Canadian Navy's 1948 Voyages into Hudson Bay and its Place in Oceanographic Research," International Journal of Maritime History 31, no. 4 (2019): 826-841, https://doi.org/10.1177/0843871419874004.

63 "HMCS Labrador: report of Summer Operations, 1957," 81/550-8000, box 54A, part 5, Department of National Defence, Directorate of History and Heritage (DHH). Please note that this report is also reproduced in Lackenbauer and Elliot-Meisel, eds., "One of the Great Polar Navigators."

${ }^{64}$ Pullen to Office of Flag Officer Atlantic Coast, H.M.C. Dockyard, Halifax, July 6, 1957, E346/8/1 vol.2, Hudson's Bay Company (HBC) Archives.

65 "HMCS Labrador: report of Summer Operations, 1957."
} 
propellers in the thick ice of Foxe Basin. Since that time, Edisto had procured two new propellers and its captain had "every intention of hanging onto them this year." Labrador's crew was pleased to reunite with Edisto but more than pleased to turn over Memphis which, Pullen recalled, was still "stumbling along several miles astern of USS Kankakee." With "some relish," Labrador left Edisto and proceeded, with Kankakee close behind, out of the Inlet and back into open water. ${ }^{66}$

Not far from Hamilton Inlet, Labrador resumed her course through dense fog and close pack ice. Visibility reduced to mere yards as the ship's bridge crew relied on their radar to spot obstacles. Pullen recalled being on the bridge when his lookout suddenly pointed "in an urgent manner" and "out of the murk came a vast mass of white towering above the ship - an iceberg undetected by radar." ${ }^{67}$ The captain ordered "all stop" and the icebreaker shuddered to a halt, brushing the iceberg with her forecastle and dumping ice across the deck..$^{68}$ The radar had been unable to tell the difference between the ice and the swells around it. The Arctic learning curve was steep; haste or impatience could lead to disaster and sometimes luck was all that stood between a ship and an unfortunate end.

A week of easier cruising brought the ship to Baffin Island, where Labrador dropped off survey crews and divers to spend a week examining and developing beaches for future use. By mid-June, with its survey work complete, the icebreaker proceeded across Davis Strait to Greenland to pick up a party of distinguished guests led by the head of the Greenland Department of the Danish Government and the Canadian ambassador to Denmark. Amongst the party was Danish scientist Dr. Niels Bohr (of Manhattan Project fame) and seven other politicians, diplomats, and scientists who had arranged the visit when Labrador was in Copenhagen the previous April. The pickup was scheduled to take place in the Greenlandic town of Narssaq but, to Captain Pullen's dismay, a survey of the maps showed three Narssaqs on

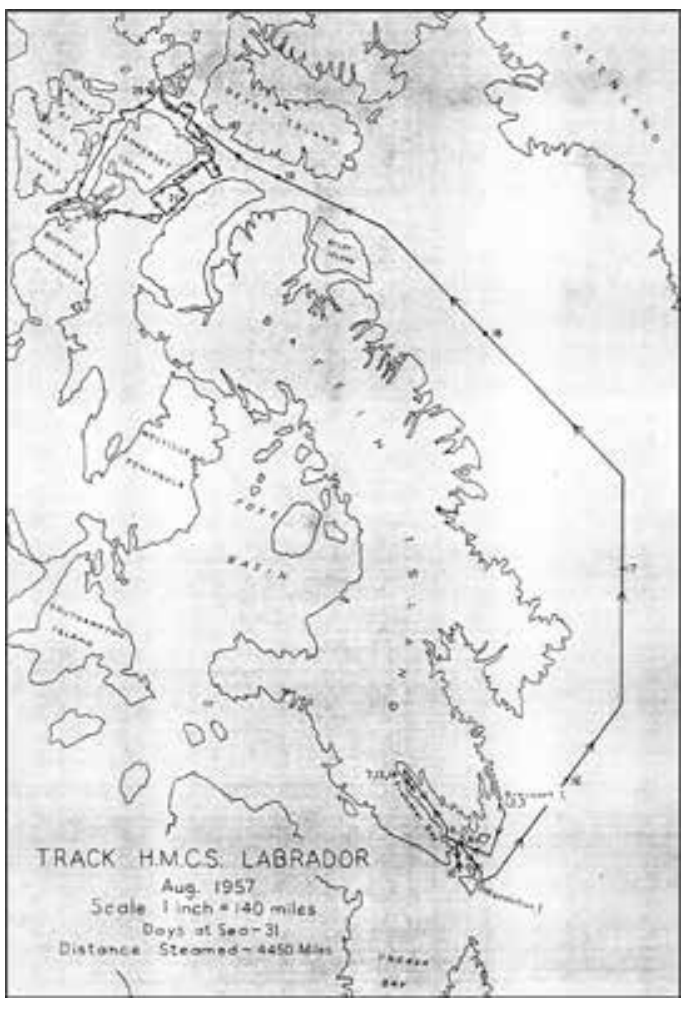

Image 3. Track of HMCS Labrador through the Northwest Passage, August 1957. (Thomas Pullen Papers, Hudson's Bay Company Archives)

66 "HMCS Labrador: report of Summer Operations, 1957."

67 "HMCS Labrador: report of Summer Operations, 1957."

68 Thomas Pullen, "We Found a New Northwest Passage," Saturday Evening Post, 10 May 1958. 
the island - one of which was on the far eastern coast. Pullen was forced to gamble and chose the nearest town. Upon arriving on 15 June, he received word from the light boat Pogo that they had guessed correctly. For five days the ship was a guest in Greenlandic waters, sailing north to Gronne Dal and Gothaab.

Its diplomatic duties complete, Labrador proceeded back across Davis Strait and reached Resolution Island, a small body off the southeast coast of Baffin Island, on 21 June. The hydrographers which the ship had left there had completed their work and were anxious to leave the foggy, windswept island. A US Air Force officer, who had left camp to go mountain climbing and had not returned, delayed the departure. Search parties from the ship were sent out and Labrador's helicopters scouring the rocky landscape soon discovered his body. The officer had apparently slipped and plunged 900 feet onto the rocks below. After recovering the body, the ship resumed with its survey work, albeit in a more sombre mood. ${ }^{69}$

Less than a week of operations along southern Baffin Island passed before the next mountaineering emergency struck. On 26 June, the ship's two Bell helicopters flew off with the hydrographer and his equipment. At 12:15 p.m. a faint voice came over the radio, reporting that "one Fan [helicopter] had crashed but both occupants were all right." The helicopter had crashed atop and then rolled down, Peter Point Mountain - a 24,000-foot peak on the south shore of Frobisher Bay. The ship's second Bell helicopter flew to the rescue, but violent wind eddies spun it out of control and smashed it against the rocks, leaving four men stranded. ${ }^{70}$ Captain Pullen called an emergency conference and participants agreed that the mountain was too dangerous to climb in the fog and wind. The storm had to be waited out. Thankfully, the captain had insisted that all helicopters carry sleeping bags and emergency supplies in anticipation of this sort of situation. Nonetheless, the stranded men had little food and water. Supplies could not be airdropped because the fierce winds would destroy any parachutes, and any water containers dropped without a parachute would explode on impact. The ship's civilian oceanographer, Arthur Collin, offered an ingenious solution: rather than drop water, why not send ice cubes that could be melted $?^{71}$ The third and final aircraft was dispatched carrying sacs of ice cubes, tins of food, and a $\mathrm{CO}^{2}$ canister filled with hot soup. The package dropped from 500 feet and landed right on target. ${ }^{72}$ It was an impressive feat given that the HUP helicopter was a larger twin-bladed machine, and less manoeuverable than the smaller helicopters preferred for Arctic operations.

All day and night, the stranded men huddled on their perch. When the next morning failed to bring a break in the weather, Pullen grew desperate and organized

\footnotetext{
69 Pullen, "We Found a New Northwest Passage."

70 Pullen, "We Found a New Northwest Passage." Pullen noted a close call on Greenland earlier that month, when a Canadian sailor on a day-long excursion whose ambition exceeded his mountaineering skills found himself trapped on a mountain face. The Danes rescued the young man, and Pullen made a point of asking Ottawa to send a formal thank-you note to the Greenlandic government. "HMCS Labrador: report of Summer Operations, 1957," 81/550-8000, box 54A, part 5, DHH.

71 Pullen, "We Found a New Northwest Passage."

72 Pullen, "HMCS Labrador: Report of Summer Operations, 1957."
} 
a volunteer party to scale the peak. Before they began, however, the storm suddenly abated. When the helicopter arrived on the mountain top, with the wind picking up and a wall of fog rolling back towards it, the four tired men hastily piled into the aircraft. The pilot lifted off even before the last man was fully aboard. Pullen recalled how "the owner of the dangling legs quickly realized he was dangling not four feet from the rocks but twelve hundred feet. He wasted no time in reaching the interior of the HUP [aircraft]." ${ }^{\prime 3}$ The dehydrated men were in generally good condition, although the soup sent to them had been so salty that they consumed their water far faster than expected.

The rescue was a success, but the ship had lost its two Bell helicopters and its remaining HUP-Retriever aircraft was unable to land on uneven ground. This was a serious problem given the ship's limited ice-spotting capacity and the aircraft's inability to land civilian hydrographers on the rocky Arctic islands. ${ }^{74}$ To compensate for the loss, the US Coast Guard loaned one of their Bells from Eastwind, which had undertaken repairs in record time and returned to the eastern Canadian Arctic to conduct resupply duties.

After its dramatic rescue efforts, Labrador returned to more routine survey and escort duties in early August. The MSTS ships required icebreaker support to enter harbours, and the Canadian vessel worked with its US Coast Guard counterparts for the next three weeks to clear paths for the convoys. Ships were stymied by ice, there were close calls on uncharted shoals, and USS Tamalpais, a 22,000ton replenishment oiler loaded with aviation fuel, nearly collided with Labrador. Nevertheless, the RCN icebreaker completed its escort duties on 20 August and entered Prince Regent Inlet, off the northern coast of Baffin Island, heading for Bellot Strait. ${ }^{75}$ Pullen was anxious to get there as there were obvious political benefits for Canada in charting the passage before the Americans did. It was also a matter of pride for the captain to achieve what he had attempted unsuccessfully the previous year. Radio interference had left the Canadians out of contact with the US Coast Guard squadron approaching from the west, so they had little sense of the progress that Captain Wood and his ships were making. "Wouldn't it be shattering," Pullen was overheard saying to his officers, "if the little American ships were already on the eastern side by the time we got there?" "When Labrador arrived at the eastern entrance to Bellot on the evening of 21 August, its captain was relieved to see that Storis, Spar, and Bramble were not there waiting.

Labrador's plan was to set up a base at Fort Ross, an abandoned Hudson's Bay Company post on Somerset Island that the ship had scouted in 1956, where

\footnotetext{
73 Pullen, "HMCS Labrador: Report of Summer Operations, 1957."

74 When asked if they would not mind being winched in and out of the HUP as it circled, the hydrographers refused. Pullen admitted that he could not blame them. Pullen, "HMCS Labrador: Report of Summer Operations, 1957."

75 "HMCS Labrador: Report of Summer Operations, 1957."

76 J.H. MacDonald, "HMCS Labrador, Bellot Strait Survey and the Northwest Passage," 81/5208000 , box 54A, part 2, DHH.
} 
the crew installed a navigation beacon to study tides in preparation for the transit. The Bell helicopter, secured from Eastwind two weeks earlier, joined the Canadian HUP in scouting obstacles along the route from the skies, while the small hydrographic survey launch Pogo took soundings on the surface. ${ }^{77}$ The bridge welcomed evidence suggesting that the channel was between 50 and 100 fathoms deep, which could accommodate even deep-draft cargo ships. The only serious obstacle appeared to be Magpie Rock - the feature that had nearly ended Labrador's career the year before. ${ }^{78}$

That evening, as the crew wound down its efforts for the day, the watch noticed a strange boat flying a homemade Canadian ensign heading towards the ship. A puzzled Pullen brought the icebreaker to a halt and allowed the small craft to pull alongside. Seven Inuit, clad in mukluks and parkas, clambered aboard. The leader explained in halting English that his settlement was caught between hunting seasons and required provisions. Pullen agreed to help and ordered his men to collect bags of flour, sugar, and tea. Twenty minutes later, with the provisions ready on deck, the crew realized that they had lost the Inuit visitors onboard the ship. A hastily organized search found the seven men in the cafeteria watching an old movie with crew members. They left reluctantly. The next day, the crew spotted the same seven Inuit, who again climbed aboard the ship. When asked what they needed, the Inuk explained that they very much wanted to see the end of the movie. ${ }^{79}$

On 22 August, Pullen prosecuted Operation Bellot in earnest. With favourable weather, the aircraft launched at the crack of dawn. Pogo and Labrador's other motor cutters were in the water, conducting survey work throughout the day and ferrying men and supplies to the temporary survey camp at Fort Ross. The aircraft and boats focused their efforts on three possible obstacles. The first was Magpie Rock, whose existence was known but not its extent. The second was a possible shoal halfway through the strait, which RCMP Superintendent Larsen reported during St. Roch's 1944 voyage. The third was possible shoal water off the western approaches to Bellot, which could prevent deep-draft ships from entering the strait. ${ }^{80}$ Pullen was elated when Pogo returned through the Strait at 1600 with good news. "Lieutenant Norton reported ... no rocks or shoals encountered except for Magpie Rock," the captain noted. "I had been given to understand there was a rock at the halfway point and there was a strong suspicion that off the western entrance, between Pemmican Rock and the Arcedeckne Islands, that shoal water might spoil our attempt to locate a deep water channel. So once Magpie is charted and a channel past it developed we're "in.",81

\footnotetext{
77 Eric Fernberg, “A Tough Little Boat: The Pogo - HMCS Labrador's Hydrographic Survey Launch," Canadian Military History 5, no. 2 (1996): 71-76.

78 Pullen, "We Found a New Northwest Passage."

79 Pullen, "We Found a New Northwest Passage."

80 "HMCS Labrador: Report of Summer Operations, 1957."

81 Pullen diary, 22 August 1957, in Lackenbauer and Elliot-Meisel, "One of the Great Polar
} 
By the end of 23 August, the triangulation work was complete, radar beacons installed, and surveying work well underway. The icebreaker and Pogo probed the strait as far as Magpie Rock when the weather changed abruptly. Ice appeared in the narrows and began to advance rapidly with the accelerating wind and tide, which tossed chunks as large as houses into the air as they moved towards the ship. Pullen ordered a retreat, however the storm soon ended as quickly as it began, reminding the crew of just how unpredictable and dangerous Arctic navigation can be. ${ }^{82}$

Watching the ship from the heights of Somerset Island, hydrographer Stewart Dunbrack and a team of crew members and civilian scientists continued the work of mapping the strait. In a spare moment, Dunbrack set off to explore the hills behind the fort. Atop one, he found a crewmember comfortable and cluelessly seated upon a pile of rocks which, the day before, the ship's photographer had used as a tripod. Dunbrack quickly recognized the pile for what it was: a cairn. Removing the top rocks, he found six bottles left by previous visitors, the earliest from the Hudson's Bay Company ship Nascopie's visit in September 1937 when its crew established the small fort. It also contained a note from 1942 from Mrs. W.A. Heslop - the only non-Indigenous woman to have wintered at Somerset Island - recounting her two years at the fort. ${ }^{83}$

The next day, Pullen decided to attempt the transit. He ordered the ship's tanks flooded to increase draft so that, if grounded, he could order the crew to "pump water like mad and raise the ship." At 9:00 in the morning Labrador set off into the fast-running eastern current with Pogo in the lead, sounding as they went. The weather was perfect and the ice relatively light. At Magpie Rock the waters were "seething" but Pogo reported sixty feet under the keel. By 9:15 the ships were past the obstacle, with Captain Pullen on the bridge shaking his fist at it. "When abeam Magpie out of the east flew a great four-engined USN aircraft stuffed with press people representing NY Times, Newsweek, Time, etc.," Pullen recorded in his diary. "It flew in at the most crucial moment. I had luckily insisted that my largest white ensign fly from the ensign staff on the flightdeck, to the annoyance I'm sure of the fliers, so that press photos would not mistake the identity of the ship. As the USN craft buzzed the ship my ensign was there large as life." 85 The jubilance was short lived. Fighting against the tidal stream overwhelmed Pogo's engines and the small boat had to be hauled aboard. While stopped to hoist it in, Labrador itself was swept back into shoal water north of Magpie Rock and, for a few tense movements, it appeared as though the icebreaker would be carried into

\footnotetext{
Navigators, " 112.

82 Pullen diary, 23 August 1957, in Lackenbauer and Elliot-Meisel, "One of the Great Polar Navigators, " 113.

83 J.H. MacDonald, "HMCS Labrador, Bellot Strait Survey and the Northwest Passage."

84 Pullen, "We Found a New Northwest Passage."

85 Pullen diary, 24 August 1957, in Lackenbauer and Elliot-Meisel, "One of the Great Polar Navigators, ”113-14.
} 
serious trouble. ${ }^{86}$ Instead, the ship recovered and resumed its course through the narrows.

Halfway through the strait the progress slowed as the ice began to thicken from $5 / 10$ to $10 / 10$ (meaning from fifty percent coverage increasing to a hundred percent). For two hours Labrador's advance was slow as it punched through thick floes. Above the ship, the clouds hung low against the high cliffs on either side, creating the impression of travelling in a tunnel. After two hours, the icebreaker cleared the strait and emerged into the open water of Peel Sound. "At "At 1125 cleared the western end and there was much jubilation, and for me, relief," Pullen recorded in his diary. "We are the fourth vessel of note to make it [after] Fort James, Aklavik, both H.B. Coy. schooners, and the St Roch, and the first of consequence, drawing 29 feet mean for this transit." He promptly signaled American and Canadian naval authorities with the news: "Passage of Bellot Strait accomplished - southbound in Franklin Strait." 88 A channel 50 feet deep had been discovered running the entire length of the strait, "the sun was shining, the sea was blue, and everybody was in good spirits." 89

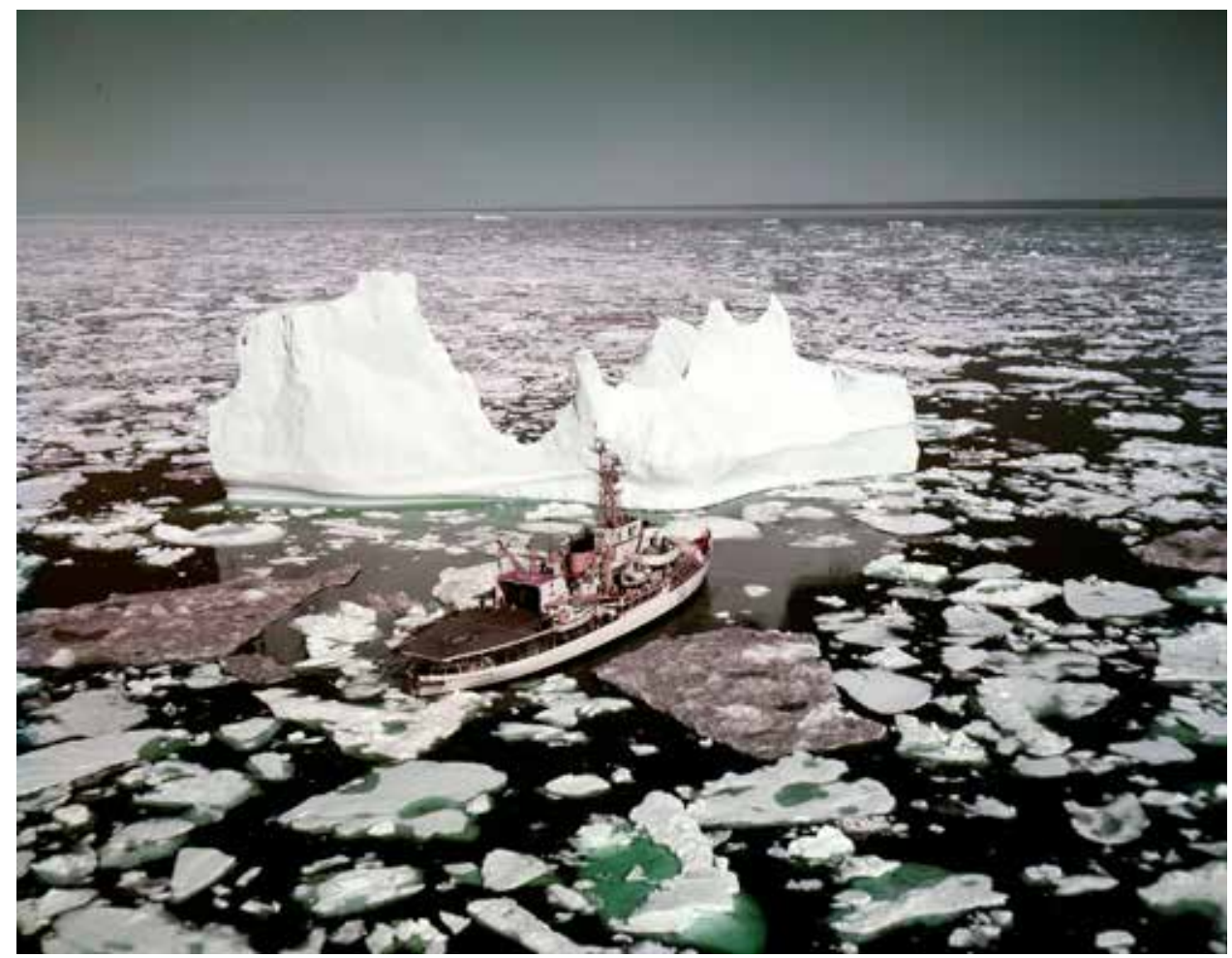

Image 4. HMCS Labrador in the ice. (Library and Archives Canada MIKAN no. 4951158)

86 "HMCS Labrador: Report of Summer Operations, 1957."

87 Pullen, "We Found a New Northwest Passage."

88 Pullen diary, 24 August 1957, in Lackenbauer and Elliot-Meisel, "One of the Great Polar Navigators, ” 114.

89 "HMCS Labrador: Report of Summer Operations, 1957." 
On 23 August, while still in Queen Maud Gulf, the US task group received word that HMCS Labrador had entered Bellot Strait. After the weeks of tough slogging through the ice in the western Canadian Arctic, the Americans were reserved in their applause, given that the Canadian icebreaker had completed a shorter and easier trip. Storis crew member James Jones lamented that Labrador was "doing a lot we should be doing." Four days later, with the American ships in James Ross Strait, Jones wrote in his log that "the Labrador is still taking all the glory." 90 Nevertheless, the American crews welcomed the news that there was a navigable strait. This meant that the task force had completed its mission and that the three US ships did not have to backtrack across the entire Canadian Arctic to gamble on an escape across Point Barrow.

To get to Bellot Strait, the task force's West Unit (TG 6.5.1) had to travel another 250 miles through potentially dangerous waters. In previous years, Storis had reached as far as Queen Maud Gulf before having to turn back. James Ross and Rae Straits were uncharted and only transited by two previous vessels. The explorer Roald Amundsen's Gjoa had run aground there in 1904 and Captain Larsen's St. Roch did the same in 1941. ${ }^{91}$ Those ships drew only 13 and 10 feet of water respectively, and Captain Wood and his subordinates feared that it might be impossible to identify a deep draft route. Records left by previous expeditions were sparse. Gjoa made many meteorological observations but took few hydrographic soundings. Although St. Roch charted its course in more detail and even included some water depths, its precise route was unclear and its records considered of dubious value. Captain Wood wrote that "to all intents and purposes, we were in virgin territory." $" 92$

As summer came to an end, the resupply convoys began retreating safely to the west. The ice above Point Barrow remained safely to the north, meaning the eastern escape route was not needed that year. As the civilian fleets exited the Arctic, the three American vessels pushed eastward into still uncertain waters. Survey work commenced at a cautious pace in Rae Strait, James Ross Strait, and Franklin Strait, given that these waters were known to be shallow and filled with uncharted shoals. Strong tidal currents posed an additional danger as they brought rock-hard old ice down into the narrow straits from M'Clintock Channel farther north. The ice break-up had been two weeks late in 1957 and areas that would normally have been clear by the end of August remained dangerous, but the ships managed to find safe passages and establish new aids to navigation. Following in the footprints of earlier explorers like Amundsen and Larsen was an honour as well as a challenge. Captain Wood wrote to his wife that "though we didn't suffer the severe hardships of early explorers, and although we had mechanical and electronic contrivances

90 Judge, The Historic Northwest Passage and the CGC Storis," 157, 159.

91 See P. Whitney Lackenbauer and Shelagh Grant, eds., "The Adventurous Voyage": St. Roch and the Northwest Passage, 1940-42 and 1944 (Antigonish: Mulroney Institute on Government, Arctic Operational History Series, vol. 7, 2019).

92 Excerpts from the Journal and Letters of Captain Harold L. Wood, USCG. 
of which those people didn't ever dream ... we're still very proud of the fact that in three short summers ... and particularly in the last one, we were able to gather for our forces, more hydrographic information about these waters than had been amassed in the last four hundred years. It's a good feeling to have had a part in something like that." 93

On 3 September, the US Coast Guard squadron under Captain Wood arrived in Franklin Strait to the southwest of Bellot Strait. There it met with Labrador, which was completing its hydrographic charting off Pasley Bay. The Coast Guard vessels tied up alongside the Canadian icebreaker for well-earned rest and celebration. The commanding officers and executive officers of all three ships were invited to a mess dinner held by Pullen in Labrador's wardroom - a "delightful dinner" followed by port, a Canadian toast to the President of the United States, and a reciprocal American toast to the Queen. ${ }^{94}$ The ships' crews enjoyed a similar exchange. For the Americans, the trip to Labrador was particularly enjoyable: while US Coast Guard vessels were dry, Royal Canadian Navy ships offered a daily rum ration. ${ }^{95}$

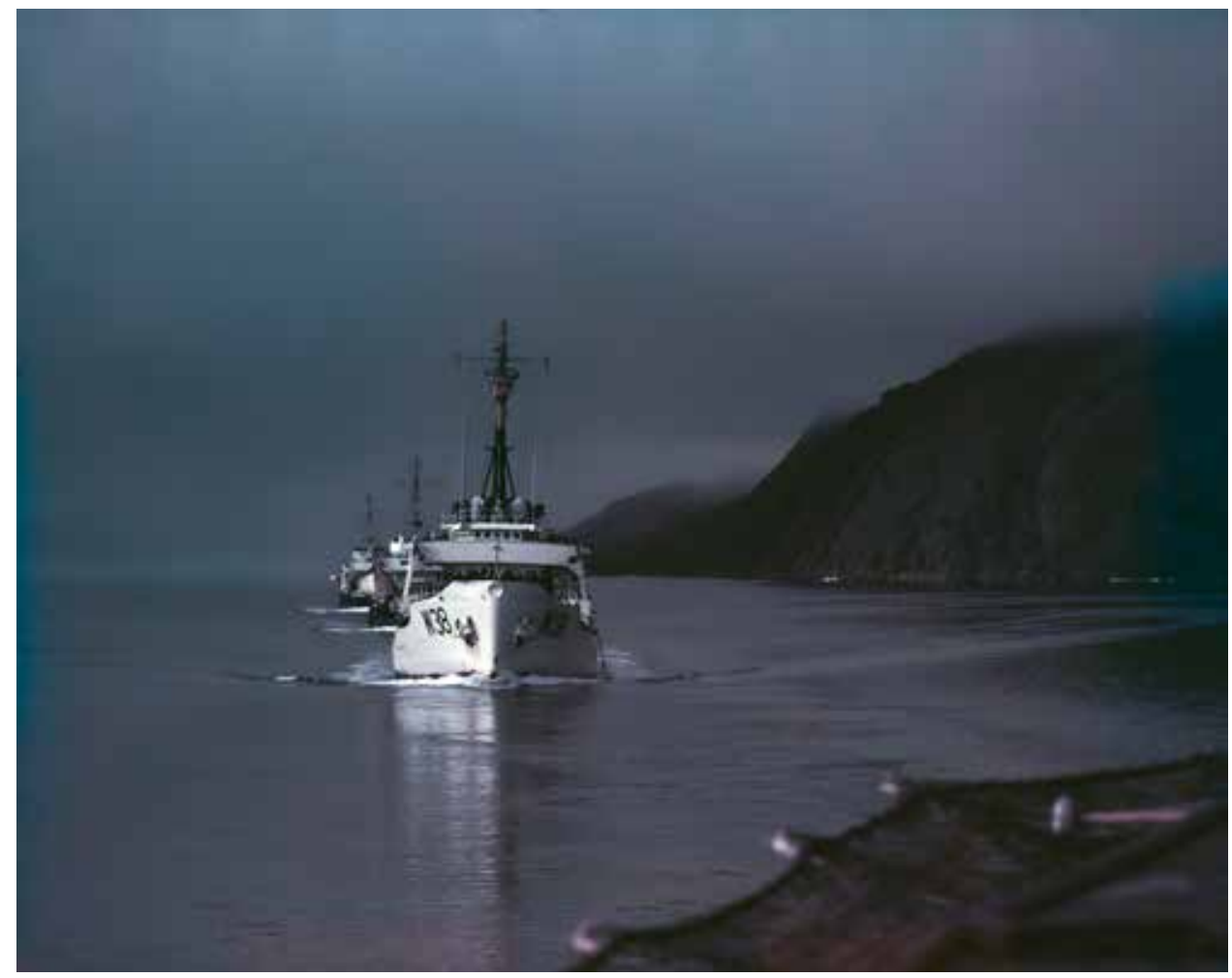

Image 5: HMCS Labrador leading USCGC Storis, Bramble, and Spar through Bellot Strait, September 1957. (Library and Archive Canada, MIKAN no. 4951194)

93 Excerpts from the Journal and Letters of Captain Harold L. Wood, USCG.

94 Excerpts from the Journal and Letters of Captain Harold L. Wood, USCG.

95 Capelotti, Across the Top of the World, 20. 
Soon thereafter the four vessels set to work charting the western entrance to Bellot Strait. Storis sent its boats to the shore to drop off a tidal observation party and pick up a Canadian team that had been there for the past ten days. The Canadians enthusiastically accepted the invitation back to the American cutter as they had only eaten canned stew heated over a fire during their time ashore - to their dismay they found that Storis' galley was serving stew that day. The American landing party erected a cairn to mark their accomplishment in which they stashed a list of the three vessels' crews, a stamped envelope addressed to US Coast Guard headquarters in Washington (so that the next explorer to arrive could send home any message they desired), and a quart of mayonnaise. ${ }^{96}$

On 6 September, the four ships proceeded through Bellot Strait in a column led by Labrador. Once clear, they landed shore parties at Fort Ross where the men marked their achievement by placing documents into the cairn that Dunbrack had discovered the week before. Moving into Prince Regent Inlet, Captain Wood brought his squadron seventy miles north to where, in 1825, Royal Navy Captain Henry Parkyns Hoppner's vessel Fury was damaged by ice and grounded on what became Fury Beach. Wood was aware of the significance of the site and made a point of examining the artifacts strewn about the beach. He picked up enough nails from the wreck site for each crew member to have one as a souvenir. ${ }^{97}$ They also brought back to the ship a selection of artifacts to be given to the Maritime Museum in Halifax.

Traveling north through Prince Regent Inlet, the American ships finally entered better-charted waters, which enabled them to engage in activities other than survey work. Looking for entertainment, the crews practiced their gunnery on a passing iceberg. The crestfallen gunners soon observed that their three-inch deck guns barely dented the hulking block of ice. Meanwhile, Labrador spent another four days completing its survey before heading home. "At 0730 I took off, with four on the line, at 14 knots and full of confidence, the ship swept past Magpie Rock and through the Strait without any hesitation," Pullen recorded in his diary on 11 September. "Stood out into Peel Sound and then north to Resolute. Goodbye to Bellot, scene of so much activity and work and worry. The job's done and done well." ${ }^{98}$ Outside applause for the achievement began arriving before the Bellot Strait survey group had even left the region. As US Navy Admiral Roy Gano messaged to Labrador on 7 September 1957:

The determination of a useable deep water channel from Shepherds Bay in the Central Canadian Arctic eastward through Bellot Strait to the open Atlantic is an achievement of the first order. Upon completion of this historic Northwest Passage from the Pacific Ocean to the Atlantic Ocean, the first time in history for any US flag vessel, I extend to all concerned my

\footnotetext{
96 Excerpts from the Journal and Letters of Captain Harold L. Wood, USCG, 4 September 1957.

97 P.J. Capelotti, "Fog, Wind, and Ice."

98 Pullen diary, 11 September 1957, in Lackenbauer and Elliot-Meisel, "One of the Great Polar Navigators, " 141.
} 
heartiest congratulations for an operation smartly and smoothly executed.

It is worthy of note that this operation was carried out with such skill and initiative as to require no directives to the Task Group during the period of its existence: that this undertaking was planned by the US Navy, executed by the Royal Canadian Navy and the U.S. Coast Guard, with the Task Group under the operational control of a Canadian officer, ice reconnaissance support was supplied by the Royal Canadian Air Force, the U.S. Hydrographic Office provided the ice forecasting: and both the RCN and. USN provided the basic communications networks. As an outstanding example of what can be achieved by Canadian and U.S. nationals of various services working together in a spirit of effective co-operation, I consider Operation Bellot to be without peer. Again my congratulations to all involved. ${ }^{99}$

Similarly, when the US Coast Guard cutters crossed the Arctic Circle on 12 September during their homeward journey, "congratulatory telegrams rained down" on the ships "from admirals and department secretaries."

By early October, all of the ships had arrived safely back at their home ports. For Labrador, the mission represented a historic success. A new Northwest Passage had been established for deep draft ships. The Royal Canadian Navy heralded it as a triumph, while the MSTS's leadership expressed relief that the danger of its ships being trapped in the Arctic had been considerably reduced. ${ }^{101}$ Captain Pullen admired the cooperative bilateral working relationship, which made the continent safe for all North Americans, regardless of borders and boundaries. But despite the Labrador's myriad successes during its 1957 mission, it ended on a dour note. While the ship was operating in Lancaster Sound on 23 September, Pullen recorded in his diary how he, Commander C.A. Law, and Commander D.E. Fairney were sitting in the captain's "cabin at about 2100 having our evening cup of coffee when a signalman handed me one of the most shattering messages I have ever received and which explained why a lot of things to us up here have seemed odd." It hit him "like a kick in the stomach," reading:

1. As a measure of economy it has been decided to transfer the operation of Labrador to the Department of Transport about 1 April 1958.

2. It is realized that this step will be deeply regretted by officers and men of the RCN particularly those who are now serving or have served in the ship.

3. However such considerations must give way to those of economy if we are to make our most effective contribution to the defence of Canada and NATO.

4. The exploits of Labrador and the reputation she has gained for efficiency have done much for the prestige of Canada and the RCN.

\footnotetext{
99 Quoted in Lackenbauer and Elliot-Meisel, “One of the Great Polar Navigators," 138-39.

100 Capelotti, Across the top of the World, 4-5.

101 J.H. MacDonald, "HMCS Labrador, Bellot Strait Survey and the Northwest Passage."
} 
As the development of the Arctic continues this work will not be forgotten. (?)

5. Further information on the programme up to 1 April will be promulgated. ${ }^{102}$

The message left Pullen and his fellow officers "stunned." The captain was dismayed at the thought of having to communicate the news to the ship's company, lamenting that this would "put the cat among the chickens." He cursed "those devils" at Naval Headquarters in Ottawa, noting specifically Captain W.M. Landymore, the Director of Naval Plans and Operations, and Rear Admiral H.N. Lay. ${ }^{103}$ "Blast their eyes. Why couldn't they have waited until we got back?" In the midst of this angst, Labrador rescued five survivors from Pamir, a German fourmast barque that capsized in the North Atlantic two days earlier. Pullen ended his diary entry for 23 September by noting: "What a black day this has been." 104

In the end, the RCN's foray into the Cold War Arctic proved brief. The Navy had little operational interest in the North, and Labrador was an anomaly in an anti-submarine warfare-oriented navy. The RCN preferred to focus on the Atlantic theatre and opted out of its Arctic role in 1958 when it paid off Labrador as a naval ship and transferred it to the Department of Transport. 105 "No ship has done more for Canada than Labrador," Pullen wrote in his diary on 11 October 1957. "No ship is better known to the people in Canada and abroad than Labrador, and yet the experts, in their purblind wisdom, have decided that she has nothing to contribute in a war that will never be fought. And so she is got rid of so that a couple of obsolete frigates can be commissioned." Even the news that the US submarine Nautilus had reached $87^{\circ} \mathrm{N}$ via Kennedy Channel "has had no effect" on senior decision-makers, Pullen lamented. "All our inspired leaders can think of is fighting World War II over again in the N. Atlantic." ${ }^{106} \mathrm{He}$ appealed to his brother, Rear Admiral H.F. Pullen, the Flag Officer Atlantic Coast, in hopes that he could convince senior leadership to reverse the decision, but his effort came to naught. Labrador's transfer to the Department of Transport was completed in 1958. ${ }^{107}$

\footnotetext{
102 Pullen diary, 23 September 1957 in Lackenbauer and Elliot-Meisel, "One of the Great Polar Navigators," 149-50.

${ }^{103}$ On these deliberations, see file "Notes used in preparing History HMCS Labrador," 81/520-8000, DHH.

${ }^{104}$ Pullen diary, 23 September 1957 in Lackenbauer and Elliot-Meisel, eds., "One of the Great Polar Navigators, " 150.

105 See also Ken Eyre, Custos Borealis: The Military in the Canadian North, ed. P. Whitney Lackenbauer (Peterborough: North American and Arctic Defence and Security Network, 2020); and J.M. Leeming, "HMCS Labrador and the Canadian Arctic," 286-307.

106 Pullen Diary, 11 October 1957 in Lackenbauer and Elliot-Meisel, "One of the Great Polar Navigators," 157.

${ }^{107}$ On the occasion of paying off Labrador, Minister of National Defence George Pearkes applauded "the splendid record established by the ship under the White Ensign." It had been the only naval icebreaker in the Commonwealth but "now, with her transfer, trained and experienced personnel will be made available to help man our fighting ships, whose operation is our primary task." Priority message, Minister of National Defence to Labrador, 21 November 1957, 81/520-8000, DHH.
} 
For the three US Coast Guard vessels involved in the West Unit of the 1957 Bellot Strait Expedition, the transit represented an equally impressive accomplishment: a 14,000-mile, triple circumnavigation of the continent. The mission marked the first transit of Northwest Passage by US ships, the first successful convoy across the route, and Bramble and Spar were the first buoy tenders to complete the passage. ${ }^{108}$ The ships left behind new navigational aids and brought back new hydrographic information and charts, encompassing nearly 2,000 miles of largely unknown sea routes stretching from the Beaufort Sea to Baffin Bay. "Even though the Storis was greeted in Boston by the vice commandant of the Coast Guard, Capt. Wood was awarded the Coast Guard Commendation Medal, and a specially-commissioned bronze plaque was bolted onto the vessel to commemorate the expedition, the magnitude of the achievement was not immediately clear," Capelotti noted. Only over time would the participants come to fully internalize the significance of the historic 1957 voyage. ${ }^{109}$

The success of the 1957 operations went far beyond the opening of Bellot Strait to deep draft ships; the broader resupply operation also highlighted Canadian and American mariners' increasing competence in Arctic operations. The initial surge of American ships into the Arctic during the 1955 season brought significant damage to the commercial and icebreaking fleet, with the MSTS alone sustaining 164 vessel casualties including 44 ships with hull damage and 13 groundings. ${ }^{110}$ Many lessons were learned from those initial voyages: steel propellers replaced bronze ones, larger ships were removed from shallower routes, and captains developed a new and healthy respect for the ice. ${ }^{111}$ By 1957, operations had become far more routine: 37 ships reported some ice damage, most of which was described as "relatively minor," and only one ship needed to be towed. ${ }^{112}$ The dangers of Arctic operations and the high costs of failure encouraged mariners to learn and adapt quickly.

For Captain Pullen, the voyage proved his strong leadership style, willingness to take risks, and skills as a polar navigator - as well as his propensity to push his ship and those in his convoy to their limits. Although his actions ultimately achieved results favourable to Canada, his impatience (particularly as the leader of a task group of ice-strengthened ships that relied upon the support of his icebreaker to operate safely) also appears to have created or amplified dangerous situations. While he blamed others for the problems that they encountered, he certainly bore some of the responsibility for mishaps or accidents that could have been avoided through prudence. "Pullen of the Arctic" emerged with the reputation as North

\footnotetext{
108 Capelotti, Across the top of the World, 5.

109 Capelotti, Across the top of the World, 14-15.

110 Cmmdr, MSTS to Chief of Naval Operations, "MSTS Arctic Operations 1955," 15 February 1955, RG 313, entry UD-13C 11, box 5, NARA.

111 Air Officer Commanding Tactical Air Command, RCAF, “Task Force 572," 27 September 1955, RG 313, entry UD-13C 11, box 8, NARA.

112 MSTS, "Post Operation Report" (1957), 4.
} 
America's foremost expert on Arctic navigation and icebreaking over the course of his life, ${ }^{113}$ but Operation Bellot demonstrated that he too faced a learning curve. Nevertheless, Pullen was successful in his mission, and his caution in mapping Bellot derived from his failure to transit the strait the previous year.

Since the Bellot Strait operation, the US Coast Guard Cutters Staten Island, Polar Sea, Polar Star, Healy, and Maple have transited the Northwest Passage on more than a dozen occasions, following in the wake of Storis, Bramble, and Spar. US Coast Guard officials are finalizing plans with their Canadian counterparts for the medium icebreaker Healy to transit the Northwest Passage on an eastward course from Dutch Harbour, Alaska, to Nuuk, Greenland, in late summer 2021. Affirming the two countries' longstanding partnership, the arrangement falls within the 1988 US-Canada Arctic Cooperation Agreement, wherein Washington "pledges that all navigation by US icebreakers within waters claimed by Canada to be internal will be undertaken with the consent of the Government of Canada." 114 During its voyage, it may cross paths with Canada's new Arctic and Offshore Patrol Vessel HMCS Harry DeWolf, which is planning to circumnavigate North America on a northern and westward course from its home port in Halifax, through the Northwest Passage, late this summer. DeWolf will be the first Royal Canadian Navy ship to make the trip since Labrador in 1957. If the ships meet, we hope that they will raise a toast to Captain Thomas Pullen, RCN, Commander H.L. Wood, USCG, and the rest of the officers and crews who preceded them sixty-four years ago, rekindling the bonds of bilateral cooperation that historically opened the Canadian Arctic to deep-draft ships and that continue to animate our Arctic relations as "premier partners" today. ${ }^{115}$

Adam Lajeunesse is the Irving Shipbuilding Chair in Canadian Arctic Marine Security Policy and an Assistant Professor at the Brian Mulroney Institute of Government, St. Francis Xavier University, Nova Scotia, Canada. (Contact: alajeune@stfx.ca)

P. (Paul) Whitney Lackenbauer is Canada Research Chair (Tier 1) in the Study of the Canadian North and a Professor in the School for the Study of Canada at Trent University, Ontario, Canada. (Contact: pwhitneylackenbauer@trentu.ca)

\footnotetext{
113 Graham Rowley, "Captain T.C. Pullen, RCN: Polar Navigator," The Northern Mariner 2, no. 2 (1992): 47; and Lackenbauer and Elliot-Meisel, eds., "One of the Great Polar Navigators."

114 Levon Sevunts, "U.S. Coast Guard to send icebreaker through Northwest Passage with Canada's consent," CBC News, 13 March 2021, https://www.cbc.ca/news/politics/icebreaker-northwestpassage-1.5948475. See also Peter Kikkert and P. Whitney Lackenbauer, "Handshakes or Arm Wrestling? The United States, Canada and Icebreakers in the Arctic," Canadian Global Affairs Institute Policy Perspective (August 2020), https://www.cgai.ca/handshakes_or_arm wrestling the united states canada and icebreakers in the arctic.

115 P. Whitney Lackenbauer and Rob Huebert, "Premier Partners: Canada, the United States and Arctic Security," Canadian Foreign Policy Journal 20, no. 3 (Fall 2014), 320-33.
} 